\title{
モデュラーコオーディネーション（MC）における 許容差の問題
}

一 $\mathrm{RC}$ 造中層アパートの例について—

\begin{tabular}{|c|c|}
\hline 正会員 ○佐 & 々 木 \\
\hline 同 川 & 井 \\
\hline
\end{tabular}

\section{1. $\mathrm{MC}$ と許容差}

MC そ捛ける許容量の問題の中で、そ の概念や意義については、すでにいくつ かの研究報告がある(1)。しかし、その具 体的な方法については、さら飞追求しな ければならない多くの問題がある。とく と許容差の設定すべき籄所と、許容差の 具体的な限界值に重点が执かれるべきで あろう。

許容差の具体的な限界值については、 すで製作施工精度という形で研究され ている部分もあるが、しかし、これは、 $\mathrm{MC}$ の立場からではない。この問題は多 くの実験資料による裹付けを必要とする ので、簡単とその結論を出すことは困難 である。

許容差の設定すべき篁所については、 これまでル “逃げ”という考方方を含め て施工段階の各所で、その場その場の問 題として処理されて来ている。しかし、 MC の立場では、これを、設計や製作の 最初から想定する。したがつて、許容差 を設定する必要のある䇠所を出来るだけ 明確にして劫かなければならない。いま その手始めとして、RC 造中圈アパート の設計例飞基いて、許容差設定の必要箘 所を抽出して、その許容差の問題を分析 して行きたい。

2. 平面における許容差

$2 \cdot 1$ 基準線間の許容差

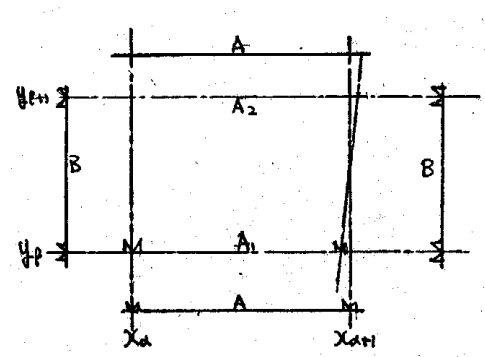

第 2 図

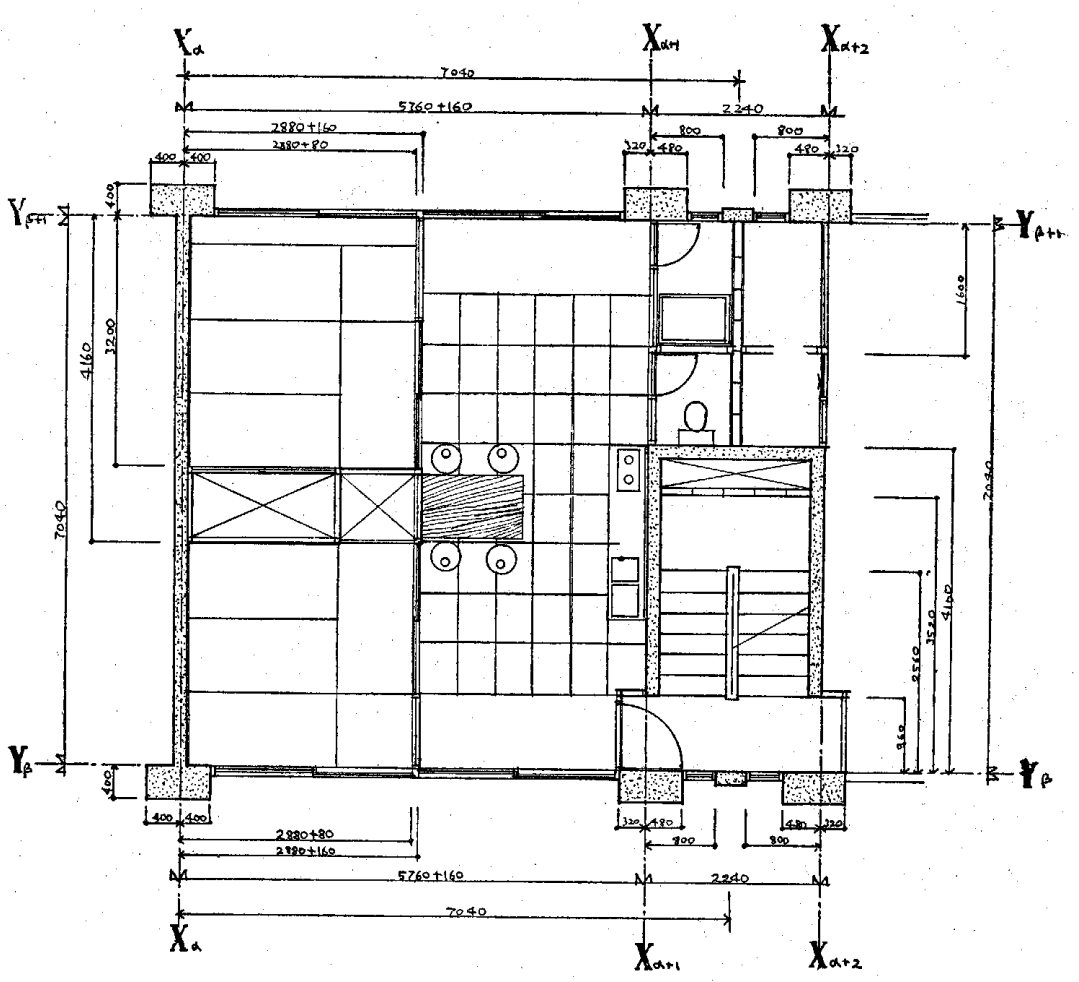

第 1-1 図

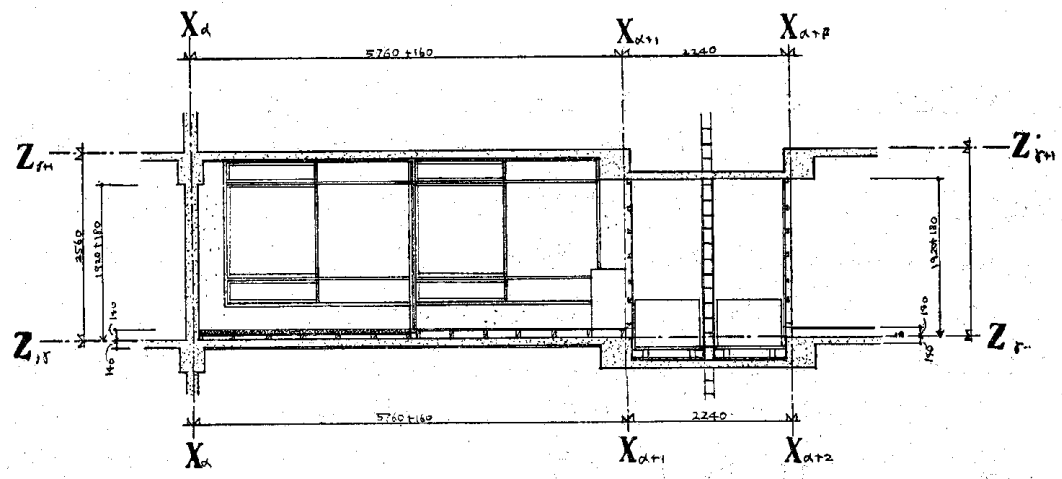

第 1-2 図

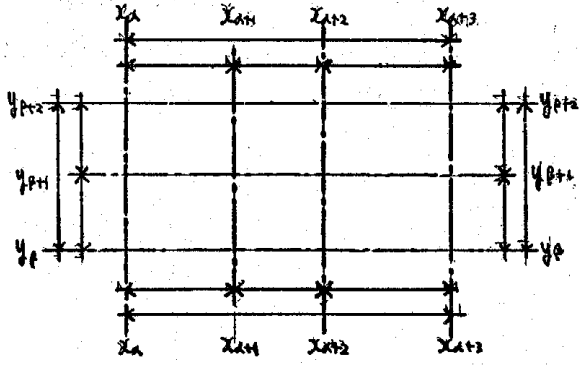

第 3 図

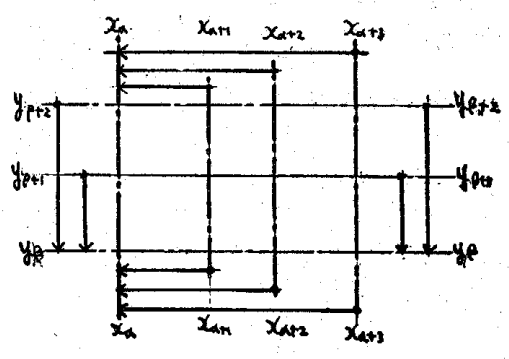

第 4 図

* 東大生研 大学院 ** 東大生研 池辺研究室 
組立基準線の位置を決定する。組立基準線間の寸法は 設計図面の上では正確な格子として考えられるから、こ の寸法㳯容差を設定することは予想されないが、しか し、実際の施工現場では必ずしも正確にマークされると とは困難な問題である。

例光ば、2図に招いて、 $x_{\alpha}, x_{\alpha+1}, y_{\beta}, y_{\beta+1}$ 基準線 とすると、 $A$ が $x_{\alpha}-x_{\alpha+1}$ の距離であるとき、 $A_{1} \gtreqless A$ き $A_{2}$ となることが予想される。これは $y$ 方向について る同様である。

このようなことの原因として考光られることは、

1. 測定器具の誤差

2. $A_{1}$ と $A_{2}$ を測定するときの誤差

3. 寸法を移しとる方法による誤差（例：墨出し）

4. 基準線の位置をマークしたるの（例：遣方等）の 移動

\section{5. 交文する基準線の角度の誤差}

などである。一般に、これらの原因は、重合つて作用す るので、個々のすのだけが精密であつても誤差を生じる ことは擗けられない。したがつて、基準線についてる、 ある一定の許容差を設定する必要がある。

3 図に招いて、 $x_{\alpha}-x_{\alpha+3}$ の間仵容差を設定したと すると、さら飞 $x_{\alpha+1}-x_{\alpha+2}, x_{\alpha_{+2}}-x_{\alpha+3}$ の間にる夫々 許容差を設定しなければならない。このとき、 $x_{\alpha}$ を主 基準線と考兄て、順次飞 $x_{\alpha_{+1}}, x_{\alpha_{+2}}, x_{\alpha_{+3}}$ の位置を決 めて行くと、夫々の許容差が累積される招それがある。

$$
\begin{aligned}
& \pm \alpha_{1}: x_{a}-x_{a+1} \text { の許容差 この } \alpha_{1}, \alpha_{2}, \alpha_{3} \text { は同じ } \\
& \pm \alpha_{2}: x_{\alpha_{+1}}-x_{\alpha_{+2}} \text { の許容差 限界值をつつのと仮 } \\
& \pm \alpha_{3}: x_{\alpha_{+2}}-x_{\alpha_{+3}} \text { の許容差 定することが出来る。 } \\
& \text { とすると、 } x_{\alpha}-x_{\alpha+3} \text { では } \\
& \left( \pm \alpha_{1}\right)+\left( \pm \alpha_{2}\right)+\left( \pm \alpha_{3}\right)
\end{aligned}
$$

の許容差となる。この值が 0 となる場合るあるが、十だ けの $\left(\alpha_{1}+\alpha_{2}+\alpha_{3}\right)$ か、一だけの $\left(-\alpha_{1}-\alpha_{2}-\alpha_{3}\right)$ Kなる ことも予想される。これは $y$ 方向についても同様である。

いま、4図のように、 $x_{\alpha}$ を主基準線として、 $x_{\alpha_{+1}}$, $x_{\alpha+2}, x_{\alpha+3}$ の各々を $x_{\alpha}$ 加測定して位置を決定するす のとし、それぞれの許容差を $\alpha_{1}{ }^{\prime}, \alpha_{2}{ }^{\prime}, \alpha^{\prime}{ }^{\prime}$ とすると、 $x_{\alpha}-x_{\alpha_{+3}}$ の許容差は $\pm \alpha_{3}^{\prime}$ となる。これを3 図の場合 と比較すると、許容差は、はるかね小さくなる。

したがつて、4図のような寸法の方法は、誤差を小さ くするのに有效である。これは、基準線だけに適用され ずに、他の各部分の寸法の押さ方方にも適用することが
望をしい性質をるつている。

\section{$2 \cdot 2$ 交叉する基準線の許容差}

相交わる二つの基準線があつて、そのなす角度が $\theta$ で あるとする。（5図）一方の基準線 $y$ を先祋定して、

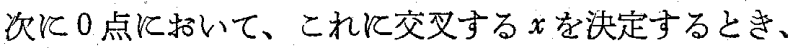
この $x$ が $y$ となす角が $\theta^{\prime}$ 又は $\theta^{\prime \prime}$ になることが予想さ れる。したがつて、このような場合についてる、許容差 の問題を考慮しなければならない。

一般飞、角度の誤差は、それが微小な值であつてる、 これをはさむ線分の長さが大きくなれば、それにつれて 弧及び弦の長さは大きくなる。この誤差は主として、指 示された角度を現場にて設定するとき、計測器具や器械 の誤差や、測量の誤差、角度を移しとるときの誤差など 前項の場合とほぼ同椂な原因をるつのと考方られる。

この場合の許容差は、角度の限界值による表現が正碓 であるが、しかし、MC の立場を含めた実際の施工製作 の段階では、0点からの距離とその位置での弦の長さの 割合で表現した方が便利である。（6図）この場合る、 基準線の問題にだけ限定せずに、他の各部についてる適 用してよいと考古られる。

\section{3 構造体の許容差}

構造体は、この例では RC 造である。コンクリート 造の場合、その工法の特性から見て、指定された寸法よ りる、柱や䇒などは大きくなる傾向がある。（7図）こ れは、型枠工法にる問題があつて、型枠の精度を上げる とコストが高くなるのが現状である。したがつて、現在 の工法では、大きくなる傾向を予想して、型染を最初か ら指定寸法よりる小さく設置して、コンクリートをセッ トしたときに、指定寸法に近似するような方法る採用さ れている。しかし、これは非常に熟練を必要とするもの で、多くの場合、必ずしる予想通りには行かず小さくし た型枠通り飞造られる場合る起り得る。これは、構造体 そ括いては、構造計算などに用いた寸法よりも小さくな るので、重要な問題である。

コンクリートのや柱壁に、壁パネル、サッシ、㘶など が取付けられる場合、柱や壁が取付けの基準線を越克て はみ出て来ると壁パネル、サッシなどが取付かなくな る。壁パネルやサッッなどが、現場生産次第に工場生産 に移行し、さらに標準化が進められている段階では、こ れらの製作寸法の許容差は、コンクリートの場合飞比較 してはるが机さいと考光てよい。したがつて、このよ

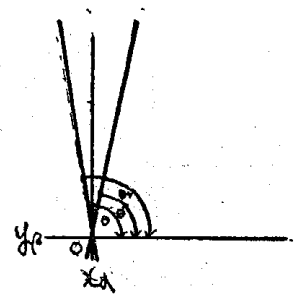

第 5 図

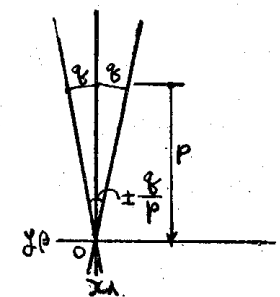

第 6 図

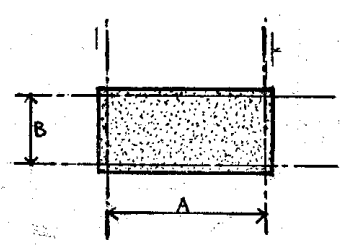

第 7 図

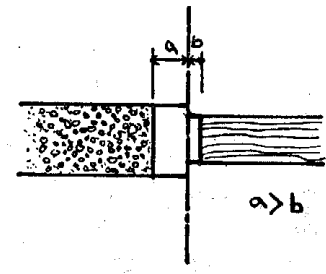

第 8 図 
うな部分では現場打のコンクリートにより大きな許容差 を設定して拾くべきだろう。（8図）

そこで、コンクリートの場合、最初から公称寸法と製 作寸法と分けて扔くことが考えられる。にの公称寸法 之製作寸法との差を公差として一定の值に決めて和く。

（9図）構造計算は、この製作寸法で行うことにすれば 前に述べたような危険は少なくなる。

2.4 平面各部に招ける許容差

次に、1図のアパートのュニットプランで許容差の設 定を必要とする籍所をあげる。

2.4.1 コンクリート壁と押入の取合せ部分

戸境壁の両端部が正確に基準線から指示された位置に めつても、真中の部分、とくに押入の部分が正負のどち らかに彎曲した場合、押入の寸法が狂つてくる。これは 押入の扉や襖の寸法にる影響を及ぼす。これは、前に述 ベたように、コンクリート壁の方に大きい許容差を与え て括くべきである。

2.4.2 コンクリート柱とサッシの取合せ部分

これは、2.4・1 そ準ずる。

$3 \cdot 4 \cdot 3$ サッシとサッシの取合せ

サッシは工場生産されるといつても、その精度にはや はり限界がある。したがつて、一般にサッシ自身も許容 差をもつて製作されなければならない。その值は、木製 サッシ、金属製サッシによつて夫々異るのは当然であ る。しかし、JIS の鋼製サッシのように枠の内側で寸法 を表示するのは MCの立場から見て望ましいことではな い。枠の外外で表示すべきである。

2.4.4 パネルとコンクリート壁の取合せ部分、

これは、2.4.1 に準ずる。

2.4 .5 パネルとサッシの取合せ部分、

これは、2.4.3 と準ずる。

2.4 .6 扉枠とコンクリートとの取合せ部分、

これは、2.4.1 に準ずる。

2.4.7 サッシや屝に括ける枠と建具

これまで、木製のサッシや屝では、枠と建具の製作が 別々に行われる習慣であるが、金属製のサッシや扉のよ うに枠と建具を一組のものとして製作しなければならな い。なぜならば、枠が現場に和いて、許容差以上の誤差 をるつて取付けられたとき、建具も常にそれに合わせて 製作されることが多いからである。（10 図）

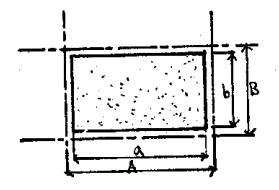

第 9 図

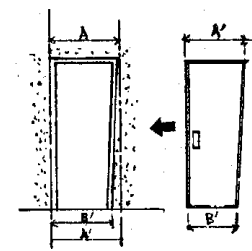

第 10 図
2.4.8 コンクリートブロック壁、

このアパートが、MC の立場から設計されたものでな
くとも、すでと公称寸法と製作寸法及び許容差の点につ いて考慮されているのは、コンクリートブロック壁であ る。目地は強度や工法の方から来る必然性によるもので あると同時に、MC の方法が導入されているるのと考え てよい。しかし、この場合でる壁面に垂直な方向に対す る許容差は、新たに設定しなければならない問題である。

\subsection{9 夕夕々寸法}

これまでに挙げた各部に扔ける許容差の問題は、公称 寸法よりる製作寸法を小さくすることとよつて解決され るものであるが、しかし、タタミ寸法は、これとは逆に 公称寸法上りる製作寸法を大きくしなければならない。 なぜならば、木栓の上うに、夕夕ミは、それ自身収縮性 を有しているから、多少無理にはめ込を方がよい。そう でなければ、従来の木造真壁の部屋に現われる“よせ” のようなるのを必要とする場合が起り得るからである。 (11 図)

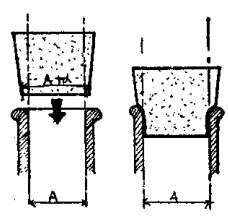

第 11 図

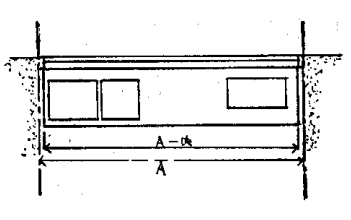

第 12 図

\section{5 設備に招ける許容差}

これは、洗面器や便器や調理台や電気のコンセントな ぞと、それらね対する配管位置との許容差の問題であ る。これらは、いまず殆んど現場で適当に処理されて 来ているが、そのために、多くの不備な点が完成后にも 残されている。とくに住宅や、アパートのよろに小規模

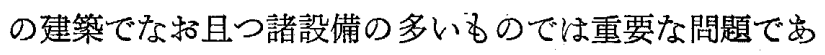
る。

\section{6 家具に括ける許容差}

一般には、家具類の製作精度は、建築のそれよりも高 いといわれているが、やはり許容差を設定して招かなけ ればならない。12 図のような調理台が三方壁の部分に 置かれる場合や、 1 図の押入部分を 2 籄ない儿 3 簀のパ 一ッの家具として製作する場合がこれである。

\section{3. 断面における許容差}

\section{1 基準線間の許容差、}

断面に却ける基準線の!位置は通常に各階の休面にとら れる。詳しくいえば、床面には

\section{1. 床下地面 2. 粗床面 3. 床仕上面} があつて、このうちどれでも基準線として考光ることは 出来る(2)。乙かし、各階の基準線は、一ケ所で粗床面に とつたなら他のどの階でる粗床面というょうに決定すべ きである。

断面計画に括ける基準線間 の許容差の設定について は、その最も望はしい方法は、平面計面に秙ける4図の ような結果になるが、この場合とくに注意しなければな 


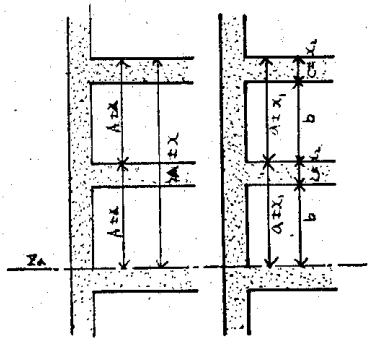

第 13 図

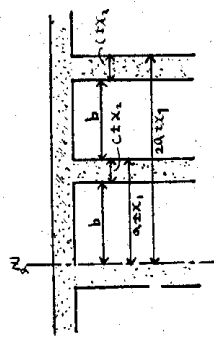

第 14 図

らないことは、断面計画では心で寸法を和さえることが ないので、13 図のように部分の寸法から括さえる場合 が起りがらだということである。この場合は 14 図のよ うに計測することが、花容差の累積を避けることが出来 る方法である。

\section{2 構造体の許容差}

上に述べた基準線というのは、図面の上ではかかる表 現をとるが、実際の建築物では水平な基準面である。 したがつて、アパートの例ではスラブ面が、この基準面 と一定の距離を有することになる。しかし、梁が沈下し たり、スラブ自身が下つたりして、水平なスラブという のは実際には非常に困難なるのである。したがつて、梁 やスラブのようなコンクリート打込み后に沈下する招そ れのある部分についても許容差を設定しなければならな い。この場合は、主に梁下端、スラブ下端が基準線を越 える傾向を持つのだから、この部分に許容差を設定しな ければならない。（15 図）

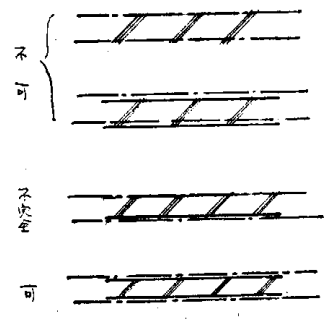

第 15 図
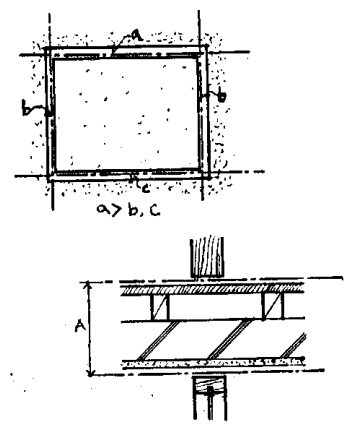

第 16 図 (上)

第 17 図 (下)
柱や壁については、2.3 の項で述べたように、主とし てコンクリート打込み后の型枠のはらみによる問題があ るが、その他に、傾斜、折れ曲り等が起り勝らなので、 これらの点をる考慮して許容差を設定しなければならな wo

3.3 断面各部に招ける許容差

2.4 に準じて、アパートの例によつて断面各部に挌け る許容差の設定について調べて見る。

3.3.1 コンクリートの柱、梁とサッシの取合せ部分

この場合は、ハメアイの䦗題であるから、機械工学に 括ける方法 ${ }^{(3)}$ が適用され得るが、コンクリート部分に ついては現場打の限り、その許容差は梁下と梁上と柱で
は各々異つた值を設定する方が妥当であろう。(16 図) 3.3.2 床・天井比招方許容差

床から天井仕上までを含むひとつの建築エレメントは それ自身の中で、構成している多くの材料の許容差の問 題を含九でいる。しかし、これが天井面、又は床面とな るとき、その不陸の点について許容差を設定すべきであ りさらに、床面に壁パネルが取り付き、天井面にとの上 端又はランマが取り付くときにも許容差を設定して沶か なければならない。(17 図)

また、タタミの表面のように水平面でなく、荷重によ つて凹凸が生じやすいるのがあるときは、粗床面、又は 下地床面に基準線を想定する方がよい。

$3 \cdot 3 \cdot 3$ サッシとサッシの取合せ部分

これは、2.4.3 そ準ずる。

$3 \cdot 3 \cdot 4$ 扉と床面の取合世部分、

じゆうたんなどを敷く場合には沓摺りを設けて、屝は 床面から離れて操作されていたが、現在の設計例の多く はこのようなディテールは少い。したがつて、しばしば 床と扉が摺り合つているのがよく見受けられる。これは 床が水平でないか、扉の釣元が不完全か、㹂枠が傾いて いるか、屝の寸法が狂つているかのどれかである。一般 には、現場で片附けているが、これを許容差の設定によ つて解決される閃題である。

$3 \cdot 3 \cdot 5$ 手替の高さ、空台の高さなど、

これらの上端位置は基準線から測定されなければなら ない。しかし、林が不陸の場合には、取り付けに問題を 生じることもある。したがつて、これらと休との取り合 せ部分に許容差を設定して扣く必要がある。

3.4 設備に招ける許容差、

これは 2.5 に準ずる。

3.5 家具に打ける許容差

原則的には 2.6 に準ずるが、高さ及びその水平面が 使用上重要なるのについては、許容差をこれまでとは別 の面から考えなければならない。例えば、テーブルの甲 板と脚の長さの関係や、柵などの台輪の問題などである。

[参考文献]

（1） EPAレポート：国際建築 1958 年1月号モデ ニール特集号

建築雑誌 1958 年 10 月号モデュール特集号

The Theoretical Basis for Solving Problems of Limits and Fits in the Building Industry, by Kaare Heiberg, Director, Norwegian Standards Association

（2）建築雑誌 1958 年 10 月号モデュール特集号 建築要素の MC 飞及ぼす影響 : 佐々木宏・川井 満、関東支部第 26 回研究発表論文

(3) EPA レポート：日本語前掲書 前掲書 by Kaare Heiberg 